\title{
Student commitment to technology in times of COVID-19: public universities in southern Peru during the bicentenary of independence
}

\author{
Elsa Emma Neira Ponce \\ Universidad Nacional de San Agustín de Arequipa \\ eneirap@unsa.edu.pe \\ Freddy Leónidas Corrales Peralta \\ Universidad Nacional de San Agustín de Arequipa
}

\begin{abstract}
Peru was no different to any other country in having to tackle Covid-19, but it did as it was preparing to celebrate the bicentenary of its independence. Great changes therefore had to be made to the celebrations as well as to other aspects of national life--especially the education sector, in which universities witnessed radical alterations to the teaching--learning process. Students had to learn using technology, despite often lacking the necessary equipment or being accustomed to other forms of learning behavior. Therefore, it is important to explore the extent to which students and their professors have been committed to the use of technology across different courses. Many studies have shown that academic engagement is a construct that encourages student learning, interest, well-being, and performance. However, a key problem in this line of enquiry involves determining the relationship between student commitment and the use of ICT in the learning process; these technologies are particularly important at present, even though some research has found that students only use it as a distraction. Therefore, in the present study we seek to determine the relationship between student commitments to learning and the technology they use in the process. In so doing we yielded an acceptable Spearman $\mathrm{R}$ correlation of 0.417 , which indicates that there is in fact a correlation between the use of technologies and student engagement. This means that students are committed to technology even when their socio-economic levels mean they cannot afford to purchase these new tools. In turn, the information we collected alongside professors indicated a moderate correlation of 0.376 , indicating that although professors are committed to teaching, they still do not have much of a relationship with technology and make limited use of it in the classroom. Thus, in sum, we found that students are closer to these forms of technology while their professors remain at a stage of adaptation.
\end{abstract}

KEYWORDS: academic engagement, technology, public education, Covid-19. 


\title{
Compromiso estudiantil con la
} tecnología en tiempos de COVID-19: universidades públicas del sur del Perú en el bicentenario de la independencia

\author{
Elsa Emma Neira Ponce \\ Universidad Nacional de San Agustín de Arequipa \\ eneirap@unsa.edu.pe \\ Freddy Leónidas Corrales Peralta \\ Universidad Nacional de San Agustín de Arequipa
}

\begin{abstract}
Resumen
Perú no fue diferente a ningún otro país al tener que enfrentar el Covid-19, pero lo hizo mientras se preparaba para celebrar el bicentenario de su independencia. Por lo tanto, hubo que hacer grandes cambios en las celebraciones, así como en otros aspectos de la vida nacional, especialmente en el sector educativo, en el que las universidades fueron testigos de cambios radicales en el proceso de enseñanza-aprendizaje. Los estudiantes tenían que aprender usando tecnología, a pesar de que a menudo carecían del equipo necesario o estaban acostumbrados a otras formas de comportamiento de aprendizaje. Por lo tanto, es importante explorar hasta qué punto los estudiantes y sus profesores se han comprometido con el uso de la tecnología en diferentes cursos. Muchos estudios han demostrado que el compromiso académico es un constructo que fomenta el aprendizaje, el interés, el bienestar y el rendimiento de los estudiantes. Sin embargo, un problema clave en esta línea de investigación consiste en determinar la relación entre el compromiso de los estudiantes y el uso de las TIC en el proceso de aprendizaje; estas tecnologías son particularmente importantes en la actualidad, aunque algunas investigaciones han encontrado que los estudiantes solo las usan como una distracción. Por ello, en el presente estudio buscamos determinar la relación entre el compromiso de los estudiantes con el aprendizaje y la tecnología que utilizan en el proceso. Al hacerlo, obtuvimos una correlación $\mathrm{R}$ de Spearman aceptable de 0,417 , lo que indica que, de hecho, existe una correlación entre el uso de tecnologías y la participación de los estudiantes. Esto significa que los estudiantes están comprometidos con la tecnología incluso cuando sus niveles socioeconómicos les impiden comprar estas nuevas herramientas. A su vez, la información que recolectamos junto a los profesores indicó una correlación moderada de 0.376 , lo que indica que aunque los profesores están comprometidos con la enseñanza, aún no tienen mucha relación con la tecnología y hacen un uso limitado de ella en el aula. Así, en suma, encontramos que los estudiantes están más cerca de estas formas de tecnología mientras que sus profesores permanecen en una etapa de adaptación.
\end{abstract}




\section{Introduction}

Peru had to face the Covid-19 crisis on the eve of the 200th anniversary of its independence, an occasion that was to be marked by major development projects. But in the event the changes that came were designed to contain the pandemic. The education sector in particular underwent great changes; as human contact diminished and the field of educational psychology had to deal with new challenges, technology became an essential element in the teaching--learning process. Our goal in this study is to detect the effects of technology on academic engagement, a key variable in the measurement of educational commitment. Many researchers study this variable to measure student motivation and performance. Yet in present circumstances technology has become an essential element for teaching, even though it does not produce change that improves the process (Nuevas Tecnologías y Educación, n.d.).

During its bicentenary, a large proportion of Peruvian education is now being carried out at a distance, drawing on the 20-year trend of competence-based virtual learning. As Peru's universities switch to virtual systems, engagement as a construct can be used to express the commitment and motivation of educators and educator against the backdrop of the pandemic (Molina et al., 2021). A body of research is beginning to emerge on Covid-19 and its effects on education. For instance, Cáceres Pinaloza has argued that the population is used to in-person classes and the shift away from this format causes fear and frustration among students and teachers (Cáceres, 2020). Other researchers (Colomina Álvarez et al., 2005), (Jordan et al., 2021) have found that education in many countries is not working as well as usual due to the emergence of a digital divide in terms of access to the internet and digital media, even though higher education has a recent history of undergoing digital transformation and facilitating access to techno-pedagogy (Díaz Guillen et al., 2021)

Studies on academic engagement at universities have shown commitment and outcomes can be sustained as challenges arise (Horstmanshof \& Zimitat, 2007), insofar as responsible decision making can overcome environmental and motivational problems, (McInnis, 2001) including the online learning necessitated by the Covid-19 pandemic. Governments around the world have closed schools and universities, resulting in the large-scale assumption of commitments to technology by educators and educated(Al-Karaki et al., 2021). This increased usage of ICT in education has had an impact at the level of the general cognitive processes involved in the completion of learning activities, tasks, and exercises(Font \& Garganté, 2008).

Engagement can be a response to the commitment, motivation, and emotions of professors and students in the situation we are living through. Technology, despite its challenges, has been a connecting element in this process, even while the virtual format has grown in importance.

\section{Instrument}

There are many ways to measure commitment. For instance, engagement analyzes the commitment of a certain population, and the tool used most frequently in the literature to measure it the Utrecht Work engagement Scale(Scale, n.d.). This instrument uses three dimensions to measure engagement--vigor, dedication, and absorption. In the present study we utilized the scale in a questionnaire, adapted to the universe of public universities in Peru and including 17 questions. Technology refers to a universe of two constructs, encompassing traditional communication technologies (CT) and information technologies, characterized by digitalized fields such as informatics and telematics(las tecnologias de la informacion y la comunicacion, 2002).

Distance learning activities have been made possible by the use of technology and the internet, even though educators today have been compelled to increase its application without necessarily analyzing the effects; for instance, whereas in in-person classes the student was the protagonist, 
that role has now been assumed by the technology itself(Diego \& Aires, 2007). To measure the technology variable, we drew on three dimensions: instrumental, cognitive, and communicative. The instrumental dimension focuses on the use of a given tool, and expresses the capacities and abilities of specific tasks based on the continual use of operating systems. The cognitive dimension refers to knowledge on the use of information, classifying it according to the quality and reliability of information sources and information overload. It is applied to real problems, using time transformed information into knowledge. Finally, the communicative dimension entails possessing the skills to create textual documents, such as the ability to interact on social media (Area Moreira, 2014). We administered a total of seven questions

Participants

For the present research, 213 students from the Business faculties of public universities in Arequipa, Puno, and Cuzco participated. Of this total, 115 (54\%) were aged between 18 and 21 years, and $202(40 \%)$ were aged between 22 and 25. In turn, 84 were male and 129 female. The students represented different stages of study: $24.4 \%$ were in their second semester, $13.6 \%$ in their fourth semester, and $25.4 \%$ in their fifth semester. Of the technological resources they used in their learning, $47.4 \%$ said that the smartphone featured most prominently, followed by laptops (34.7\%) and desktops (17.4\%). We also collected information from professors, with a final takeup of 24 , of whom $70.8 \%$ were men and 29.2 women. Of this number, $41.7 \%$ were aged 51 to 60 years, $16.7 \% 41$ to 50 , and $20 \% 31$ to 40 years. The technological resources they use most are laptops $(66.7 \%)$ followed by desktops $(25 \%)$ and smartphones $(8.3 \%)$.

\section{Results and discussion}

First, we conducted an evaluation of the participating students and professors. Of the sample of 213 students, 92 were enrolled at Universidad Nacional de San Agustín in Arequipa, 102 at Universidad Nacional del Altiplano in Puno, and 18 de la Universidad de San Antonio de Abad in Cusco. As noted above, $39.4 \%$ were male and $60.6 \%$ female. Meanwhile, of the 24 participating professors, a majority were male. The most-used device among the students was the smartphone, whereas for professors it was the laptop, which they may have found more accessible for using in their classes. But overall, the results indicate greater commitment to technology among the students.

Then we performed the Kolmogorov-Smirnov test for normality with a significance level of 0.00 , reflecting non-parametric data. We observed no data with a significance level of more than $5 \%$. We also used Cronbach's alpha to test for reliability, obtaining an alpha of 0.921 for the engagement variable and 0.849 for the technology variable. We found no previous research on the correlation between the two variables of study, and the number of studies related to ICT and academic engagement(Ballesteros Herencia, 2019) is limited. We proceeded to look for the correlation of the variables at the student level, obtaining a Spearman's rho of 0.417 with a significance level of 0.0. The relationship between engagement and technology exhibits a good correlation; at the teacher level the correlation of the two variables was 0.376 , also exhibiting a good correlation but with a significance level of 0.07 . In turn, we analyzed each of the dimensions to identify which of them did not reach levels of correlation. We also analyzed the correlations of the dimensions, and the results were as follows: for the instrumental dimension, absorption (0.088); vigor (0.264); and dedication (0.193), and at the teaching level, absorption (0.242), vigor (0.272), and dedication (0.274). For the cognitive dimension, absorption (0.307) vigor (0.2), and dedication (0.4), and at the teaching level, absorption (0.08), vigor (-0.147), and dedication (- 
$0.103)$. For the communicative dimension, absorption (0.252) vigor (0.377), and dedication $(0.370)$, and at the teaching level, absorption (0.639), vigor (0.168), and dedication (0.220).

University education has shifted away from a purely in-person format, with the exact activities involved in this change varying depending on the course and the curriculum. Adapting to these changes amid our new social reality entails a certain level of student commitment (Cajas Bravo et al., 2020).

In this study, we found that absorption (which refers to students' experience and enjoyment of the activity) (Mirvis, 1991) has a moderate correlation with the instrumental dimension (which measures knowledge of software and hardware) and can include data management programs as well as knowledge-generation instruments such as calculators and laptops (Diego \& Aires, 2007). However, the technology used as a foundation for teaching can be subject to various forms of criticism, in that it can impede the human connection and thus the level of enjoyment. Moreover, as familiar as students may be with the technology, they may feel that it detracts from a sense of involvement in their activities. It turn, having analyzed the dedication dimension. we found that teachers have yet to fully commit to teaching with technology commitment to teaching with technology (W. B. Schaufeli \& Bakker, 2004).

With regard to students, we detected a low but acceptable correlation; that is, the students were enthusiastic and proud about their education, with the challenges it entails (Mirvis, 1991). With regard to the professors, we found a very low correlation, possibly because they are not accustomed to using these forms of technology and so they lack enthusiasm for it. In the vigor dimension, which measures the levels of energy and effort involved in carrying out activities, including self-confrontation (Wilmar B. Schaufeli \& Bakker, 2004), the correlation with the instrumental dimension at student level was low but acceptable, indicating that students do exhibit some energy and effort in pursuing their objectives. Teachers also manifest energy when carrying out their activities, but the instrumental dimension makes the correlation very low.

Meanwhile, in the cognitive dimension, which refers to the abilities to analyze, select, and search for the appropriate information by allowing the intelligent use of technology (Cáceres, 2020), we found a moderate correlation (0.40) for the students but a highly acceptable level of dedication, finding a correlation of 0.40 . At the professor level there was no correlation, possibly because they are not in the habit of searching for information through technology, and so there is no relationship between absorption, dedication and vigor at the cognitive level.

In the case of the communication dimension, which reflects the ability to transmit information through a technological medium, we found a moderate correlation of 0.37 at student level. In turn, for the professors, we observed a high absorption level of 0.639 , which may reflect their experience in maintaining their focus on their activities. The levels of dedication and vigor for the teaching group were subject to a low correlation ( 2.20 and 0.168 , respectively).

Many studies have found that dropping out of classes, lack of interest, and performance are elements that result from the commitment assumed in the learning process. The commitment assumed by students and the technology used are important factors in positive learning behavior. This is consistent with the results obtained by Arenas and Andrade (2013), who noted that "absorption is characterized by full concentration and happiness at work, effectiveness in fulfilling responsibilities, and the feeling that "time flies by" (citing Salanova, Schaufeli, Llorens; Shimazu \& Schaufeli). These two scholars used the Pearson correlation index to compare 
absorption with opportunities for the use and development of skills and knowledge, obtaining a result of 0.30 and noting that a medium score was obtained for the absorption dimension. This led them to conclude that workers are moderately satisfied and manage to concentrate on the fulfillment of their responsibilities. The same was true when analyzing the correlation with technology (Organización et al., 2013), which allows it to be inferred that, in general, there is a positive mental health among workers, encompassing commitment, persistence, and enthusiasm related to work. Likewise, they found a correlation with the communication dimensions of the technology variable.

\section{Conclusions}

The bicentenary of Peru's independence came amid forced changes to the use of technologies, which have long been considered solutions that placed information within reach even though preparation and knowledge regarding its use was lacking--especially in the public sector, where a lack of resources and acquisition has led to inadequate online connections.

We measured the commitment of professors and students at public universities in the south of Peru to technology in order to determine, amid the pandemic and the independence anniversary celebrations, whether the country is prepared for the enforced changes to forms of learning. We found that public-sector universities have yet to overcome technological challenge, possibly due to lack of resources. This was something we observed when collecting the information online, in that many students and teachers did not have internet connections to complete the online questionnaire.

We found that students express some acceptance of technology, observing low but acceptable correlations with commitment and technology use. On the other hand the professors, still largely accustomed to the blackboard, are still in the process of adapting; the correlations for them was very low, and in some dimensions no relationships were found whatsoever.

\section{References}

Al-Karaki, J. N., Ababneh, N., Hamid, Y., \& Gawanmeh, A. (2021). Evaluating the Effectiveness of Distance Learning in Higher Education during COVID-19 Global Crisis: UAE Educators' Perspectives. Contemporary Educational Technology, 13(3), ep311. https://doi.org/10.30935/cedtech/10945

Area Moreira, M. (2014). La alfabetización digital y la formación de la ciudadanía del siglo XXI. Revista Integra Educativa, 7(3), 21-33.

Ballesteros Herencia, C. A. (2019). La representación digital del engagement: Revista de Comunicación, 18(1), 215-233. https://doi.org/10.26441/rc18.1-2019-a11

Cáceres, K. F. (2020). Educación virtual: Creando espacios afectivos, de convivencia y aprendizaje en tiempos de COVID-19. CienciAmérica, 9(2), 38-44. http://dx.doi.org/10.33210/ca.v9i2.284

Cajas Bravo, V., Paredes Perez, M. A., Pasquel Loarte, L., \& Pasquel Cajas, A. F. (2020). Habilidades sociales en Engagement y desempeño académico en estudiantes universitarios. Comuni@cción: Revista de Investigación En Comunicación y Desarrollo, 11(1), 77-88. https://doi.org/10.33595/2226-1478.11.1.405 
Colomina Álvarez, R., Mauri Majós, T., Coll Salvador, C., \& Onrubia, J. (2005). La calidad de los contenidos educativos reutilizables: diseño, usabilidad y prácticas de uso. RED: Revista de Educación a Distancia, 2, 4.

Díaz Guillen, P. A., Andrade Arango, Y., Hincapié Zuleta, A. M., \& Uribe Uran, A. P. (2021). Análisis del proceso metodológico en programas de educación superior en modalidad virtual. Revista de Educación a Distancia (RED), 21(65), 1-41. https://doi.org/10.6018/red.450711

Diego, L., \& Aires, B. (2007). PROFESORES Y ESTUDIANTES HACIÉNDOSE COMPETENTES CON LAS TIC : UNA VISIÓN GLOBAL Alejandra Bosco ( 2007 ) 889- UAB. 11.

Font, M., \& Garganté, B. (2008). Psicología de la educación virtual . Enseñar y aprender con las tecnologías de la información y. January.

Horstmanshof, L., \& Zimitat, C. (2007). Future time orientation predicts academic engagement among first-year university students. British Journal of Educational Psychology, 77(3), 703-718. https://doi.org/10.1348/000709906X160778

las tecnologias de la informacion y la comunicacion, (2002). http://hdr.undp.org/sites/default/files/venezuela_2002_es.pdf

Jordan, K., David, R., Phillips, T., \& Pellini, A. (2021). Education during the COVID-19: crisis Opportunities and constraints of using EdTech in low-income countries. Revista de Educación a Distancia (RED), 21(65), 1-15. https://doi.org/10.6018/red.453621

McInnis, C. (2001). Researching the First Year Experience: where to from here? Higher Education Research \& Development, 20(2), 105-114. https://doi.org/10.1080/07294360120064376

Medrano, L. A., Moretti, L., \& Ortiz, A. (2015). Medición del Engagement Académico en Estudiantes Universitarios. Revista Iberoamericana de Diagnostico y Evaluacion Psicologica, 1(40), 114-124.

Mirvis, P. H. (1991). Flow: The Psychology of Optimal ExperienceFlow: The Psychology of Optimal Experience, by Csikszentmihalyi Michael. New York: Harper \&amp; Row, 1990, 303 pp., \$19.95, cloth. Academy of Management Review, 16(3), 636-640. http://journals.aom.org/doi/10.5465/amr.1991.4279513\%0Ahttps://www.tandfonline.co m/doi/full/10.1080/00222216.1992.11969876\%0Ahttps://www.cambridge.org/core/pro duct/identifier/9780511621956/type/book

Molina, O. E., Reynaldo, D., Cancell, F., \& Hernández, G. (2021). El engagement en la educación virtual : experiencias durante la pandemia COVID-19 Engajamento na educação virtual : experiências durante a. Linguagem e Tecnologi, 17. https://doi.org/10.35699/19833652.2021 .33936

Nuevas tecnologías y educación. (n.d.). Retrieved July 13, 2021, from http://pepsic.bvsalud.org/scielo.php?script=sci_arttext\&pid=S167610492005000100007

Organización, U. N. A., Sector, D. E. L., La, S. D. E., \& Cali, C. D. E. (2013). Disponible en: http://www.redalyc.org/articulo.oa?id=79829185005.

Scale, W. E. (n.d.). Utrecht work engagement scale.

Schaufeli, W. B., \& Bakker, A. B. (2004). Utrecht work engagement scale Preliminary Manual Version 1.1. Occupational Health Psychology Unit Utrecht University, December, 1-60. https://doi.org/10.1037/t01350-000

Schaufeli, Wilmar B., \& Bakker, A. B. (2004). Job demands, job resources, and their relationship with burnout and engagement: A multi-sample study. Journal of Organizational Behavior, 25(3), 293-315. https://doi.org/10.1002/job.248 